\title{
THE DEVELOPMENT OF A LATE WEICHSELIAN - EARLY HOLOCENE SUBAQUEOUS ICE-CONTACT FAN, TEIKANGAS, SW FINLAND
}

\author{
JUHA PEKKA LUNKKA and PENTTI ALHONEN
}

LUNKKA, JUHA PEKKA and ALHONEN, PENTTI 1996: The development of a late Weichselian - early Holocene subaqueous ice-contact fan, Teikangas, SW Finland. Bull. Geol. Soc. Finland 68, Part I, 34-49.

The depositional environment of the Teikangas formation in southwestern Finland has been studied. The formation is an isolated, ice marginal accumulation of coarse-grained sediments north of the Hämeenkangas ridge, related to the Weichselian ice sheet. The results indicate that the Teikangas feature represents subaqueous ice-contact fan built by the onlapping of several smaller fans that have prograded from different directions. The fan system was developed during the final retreat of the Weichselian ice-sheet (the Näsijärvi-Jyväskylä Lobe), at its terminus in the Baltic Yoldia Sea.

Key words: ice-marginal features, submarine fans, lithostratigrahy, lithofacies, diamicton, diatom flora, deposition, Yoldia Sea, Holocene, Weichselian, Teikangas, Ikaalinen, Finland

Juha Pekka Lunkka and Pentti Alhonen, Department of Geology, University of Helsinki, P.O. Box 11, FIN-00014 University of Helsinki, Finland

\section{INTRODUCTION}

It is well known that the large, extensive Salpausselkä ridges in southern Finland (Fig. 1) are ice-marginal features deposited partly in the Baltic Ice Lake and in the subsequent Yoldia Sea during the Younger Dryas time (Saarnisto 1991). However, the detailed history of the Weichselian deglaciation in the area north of Salpausselkäs is still largely unknown. Based on the geomorphological evidence, ice-flow indicators and till stratigraphy in southern and western Finland, another extensive ice-marginal, geomorphological complex, termed the Central Finland ice-marginal formation (Kujansuu \& Niemelä 1984; CFIMF in Fig. 1), is thought to have been formed in front of the ice lobe(s) during the stillstands and minor oscillations of the retreating Weichselian ice sheet (see Virkkala 1963; Aartolahti 1972; Rainio et al. 1986; Punkari 1989; Rainio 1991; Nenonen 1992). The details of the ice-lobe(s) behaviour and the depositional palaeoenvironments along the ice margin during the deposition of the CFIMF are rather uncertain 


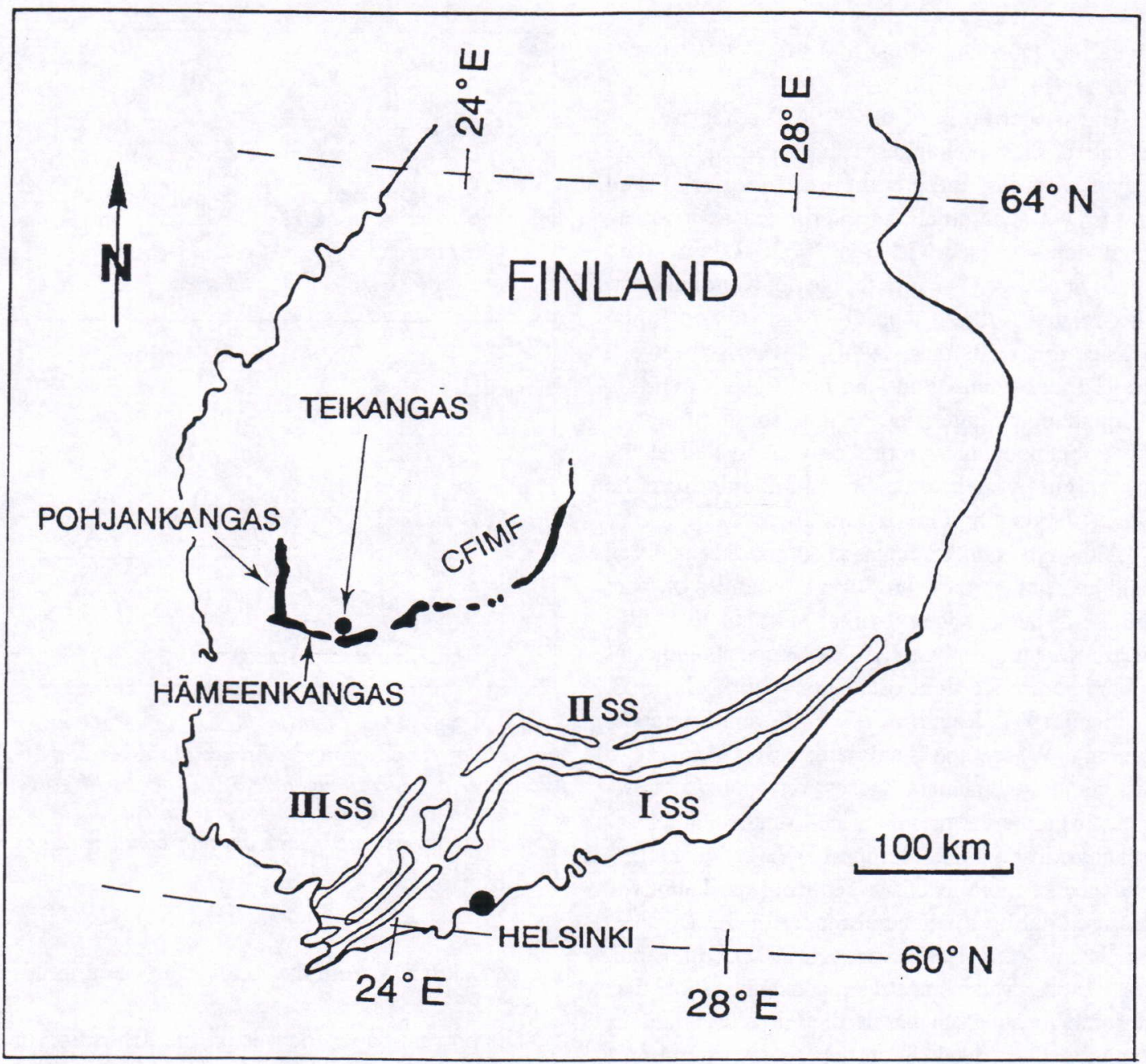

Figure 1. Location of Teikangas in relation to the main ice marginal formations in southern Finland. I - III $S S=$ the Salpausselkä end moraines; CFIMF = the Central Finland ice marginal formation, its western part Hämeenkangas, as well as the south-north trending Pohjankangas are also indicated.

and subject of some controversy. In this paper the authors discuss the depositional palaeoenvironments that existed during the time when the Teikangas formation, only $7 \mathrm{~km}$ north of the CFIMF, accumulated.

The timing of the CFIMF deposition is inferred largely from the varved-clay chronology, because organic sediments suitable for radiometric dating are lacking. Previous calculations based on the varvedclay chronology suggested that the CFIMF was formed at 9800 - 9700 (9 650) BP (see Rainio et al. 1986; Saarnisto 1991). However, the revised Swedish varve chronology and its extension to Finland indicates that the 'Finnish zero year' i.e., the drop of the Baltic Ice Lake water level to the Yoldia Sea level, dated at 8213 B.C. (Sauramo 1958), occurred c. 480 years earlier than previously anticipated (cf. Strömberg 1990; see also Saarnisto 1991). This suggests that the CFIMF was more probably formed at the transition from the Younger Dryas to the Pre- 
boreal chronozones, at 10 300-10 150 BP (Saarnisto 1991).

The western part of the CFIMF comprises the so-called Hämeenkangas ridge (Fig. 1), which strikes west-east and is composed of series of sand and gravel accumulations interpreted as ice-marginal deposits (see Virkkala 1963; Rainio et al. 1986) or as part of an interlobate depositional complex related to the Näsijärvi-Jyväskylä and Baltic Sea ice-lobes (Punkari 1989). Towards the west, the Hämeenkangas joins the north-south trending Pohjankangas ridge (Fig. 1). The southern part of the Pohjankangas was probably deposited at the ice margin by melt water flowing mainly from the west (Lunkka and Gibbard, in review).

Although Hämeenkangas is composed mainly of sand and gravel, there are several localities on both the ice-distal and ice-proximal sides of this ridge where the lithostratigraphy of the deposits indicates contemporary ice-front oscillations (Virkkala 1963; Alhonen 1971, Rainio et al. 1986, and references therein). Where the sand and gravel underlie a diamicton, sedimentary succession could be interpreted as representing minor ice-front oscillations or subaquaeous sediment slumps. However, there is also evidence of more extensive ice-front oscillations in this area during the general retreat of the ice sheet (see Rainio et al. 1986; Nenonen 1992). Lithostratigraphic observations near Hämeenkangas show that, at some localities, a basal till unit is overlain by rhythmically bedded silt and clay which in turn are overlain by another till unit (Alhonen 1971; Rainio et al. 1986; Nenonen 1992). Clast-fabric measurements from the lower till unit suggest that the ice movement was initially from the west or northwest (see Virkkala 1963; Nenonen 1992). In the upper till unit, the clasts are orientated north-south and suggest an ice movement from the north at that stage. The prevalent orientations of striae on the bedrock support this interpretation.

The highest water level in the Baltic Basin just after the formation of the Hämeenkangas was at or a few metres above $180 \mathrm{~m}$ a.s.l. (Virkkala 1963; Alhonen 1971; Aartolahti 1972; Eronen \& Haila 1990). This highest palaeoshoreline can be seen on the slopes of Vatulanharju in Hämeenkangas (Fig. 2),

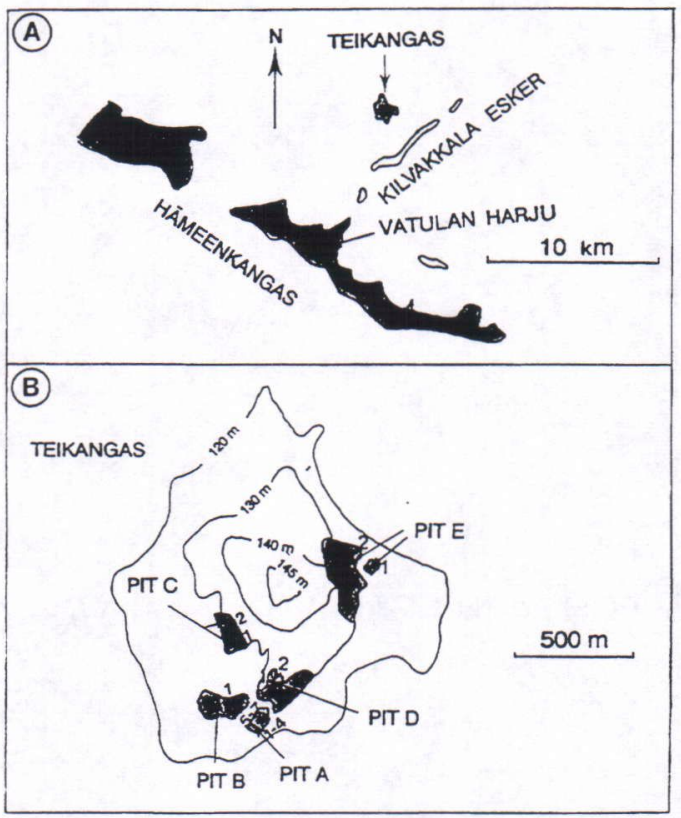

Figure 2. A) Location map of Teikangas on the proximal side of Hämeenkangas. Kilvakkala esker and Vatulanharju are also indicated, B) Locations of gravel pits studied at Teikangas (numbers indicate locations of sections investigated) and altitude contours above the present sea level.

merely $7 \mathrm{~km} \mathrm{SW}$ from the locality discussed in this paper.

The present paper focuses on the deposition of the relatively well-exposed Teikangas formation, which occurs on the ice-proximal side of the icemarginal feature Hämeenkangas (Figs. 1 and 2). The primary aim of this paper is to discuss the main depositional events involved in the development of the Teikangas formation and to reconstruct the contemporaneous palaeoenvironments that existed during its accumulation. Because the sediment succession at Teikangas comprises subaquatic fan deposits overlain by a diamicton unit including rhythmite beds, the secondary aim here is to determine the origin of this diamicton in order to establish its relationship to the local till stratigraphy. 


\section{METHODS}

The sedimentary nature, geometry and interrelationships of major lithostratigraphic units have been determined by lithofacies mapping, combined with the detailed structural and textural measurements in the outcrops. Conventional leveling was used to determine the actual altitudes of the localities investigated. The logging technique used was modified for the purpose of the present study following the lithofacies codes postulated by Eyles et al. (1983). The lithofacies logging in adjacent localities was used to determine the lateral extent and vertical variation of the sedimentary units, and thus to gain a better insight into the pattern of sedimentation and the spatial distribution of the depositional environments.

The orientation of current-induced structures was measured by palaeocurrent disc and compass to define the general flow directions during the deposition. Clast-fabric measurements were taken from the diamictons to gain information on their genesis (cf. Dreimanis 1976). The structural orientation of folds and faults (i.e., the dip and strike of principal planes, fold axes etc.) found in the deposits below the diamicton was measured to establish the general stress field during the deformation (Lunkka 1994).

A total of 12 diatom analyses were carried out on samples of selected deposits (the rhythmicallybedded silt and clay strata and the fine-grained diamicton in pit $\mathrm{A}$, section 1) in order to assess the contemporaneous water conditions. Samples 1-11 contained sufficient amount of diatom remains to permit micropalaeontological analysis. However, only a few frustules were found in the three uppermost samples and the topmost sample contained no diatoms. The preparation of the samples included treatment with $\mathrm{H}_{2} \mathrm{O}_{2}$ (30\%) for destruction of organic matter and the minerogenic fraction was removed by decanting. Slides $(24 \times 30 \mathrm{~mm})$ were prepared using Caedax (R. I. 1.56) as the mounting medium.

The taxonomy of the diatoms follows the halobian system of Simonsen (1962) to indicate environmental conditions in which the sediment has accumulated. The diatom taxa were divided into three groups: poly-, meso-, and oligohalobous types. In the diatom diagrams (see Fig. 8), the polyhalobous and mesohalobous species found in the Teikangas section are plotted as a single group, whereas the oligohalobous species include ordinary freshwater forms.

\section{LOCATION OF THE FORMATION AND SECTIONS STUDIED}

The Teikangas area is on the ice-proximal side of the Hämeenkangas ridge, $c .7 \mathrm{~km} \mathrm{NE}$ of the latter (Fig. 2A). The summit of Teikangas is at $147 \mathrm{~m}$ a.s.l. Gravel and sand deposits extend down to below the $110 \mathrm{~m}$ a.s.l. contour, but the full thickness of the formation is unknown. The geomorphology of the Teikangas hill is asymmetric, with the northeastern slope considerably steeper than the southwestern slope. The Kilvakkala esker runs NE-SW only $c .1 \mathrm{~km}$ SE of the Teikangas (Fig. 2A). This esker is thought to have been the feeding system responsible for the relatively thick accumulation of sediment in the Vatulanharju area (Fig. 2A), whose relief reaches $187.6 \mathrm{~m}$ a.s.1..

The deposits of the Teikangas formation are well-exposed in the sand and gravel pits located mainly in the southern part of this hill (Fig. 2B), with subordinate outcrops in the eastern part. Unfortunately, there are no outcrops in the northern part, and also the laterally extensive eastern exposures are largely obscured by modern talus. In some of the outcrops, the uppermost part (1-9 m thick) of the sedimentary succession is unpreserved. This is the case particularly in pit A (sections 5-7), where the uppermost 8-9 $\mathrm{m}$ of the deposits are lacking. Similarly, c. 1-3 m was lacking at the top of sections 1-4 in pit $\mathrm{A}$, and also in pits $\mathrm{B}$ and $\mathrm{C}$.

\section{DESCRIPTION OF THE DEPOSITS}

\section{Pit A (sections 1-4)}

Seven sections were logged in Pit A (Figs 2B and 3). Sections 1-4, in the eastern part of the pit A, show four main sedimentary units described here from the base of the exposure. 
The basal unit comprises planar cross-bedded sand and gravel that are slightly deformed by faults in places and represent facies Sd (p), Gp (Gcp). Palaeocurrent measurements in this unit indicate palaeoflow from the southeast (Fig. 3). Faults in the deformed sands in sections 2 and 4 are normal with a mean fault-plane dip of $30^{\circ}$ towards the southwest (Fig. 4 A).

This basal unit is overlain by deformed sands and gravels, representing facies Sd, Gd. The contact between these two units is sharp.
Matrix-supported stratified silt and sand diamicton that represents facies Dms and overlies the deformed sand and gravel unit. The stratification in section 1 is due to laterally continuous silt and clay interlayers in the diamicton matrix. Dropstones are also common in this unit. The diamicton in sections 2-4 is coarser (sandy) than in section 1, and stratification in these former sections arises from sand bands, streaks and small isolated blocks of laminated mud interbedded with the sand diamicton. The boundary between the sandy

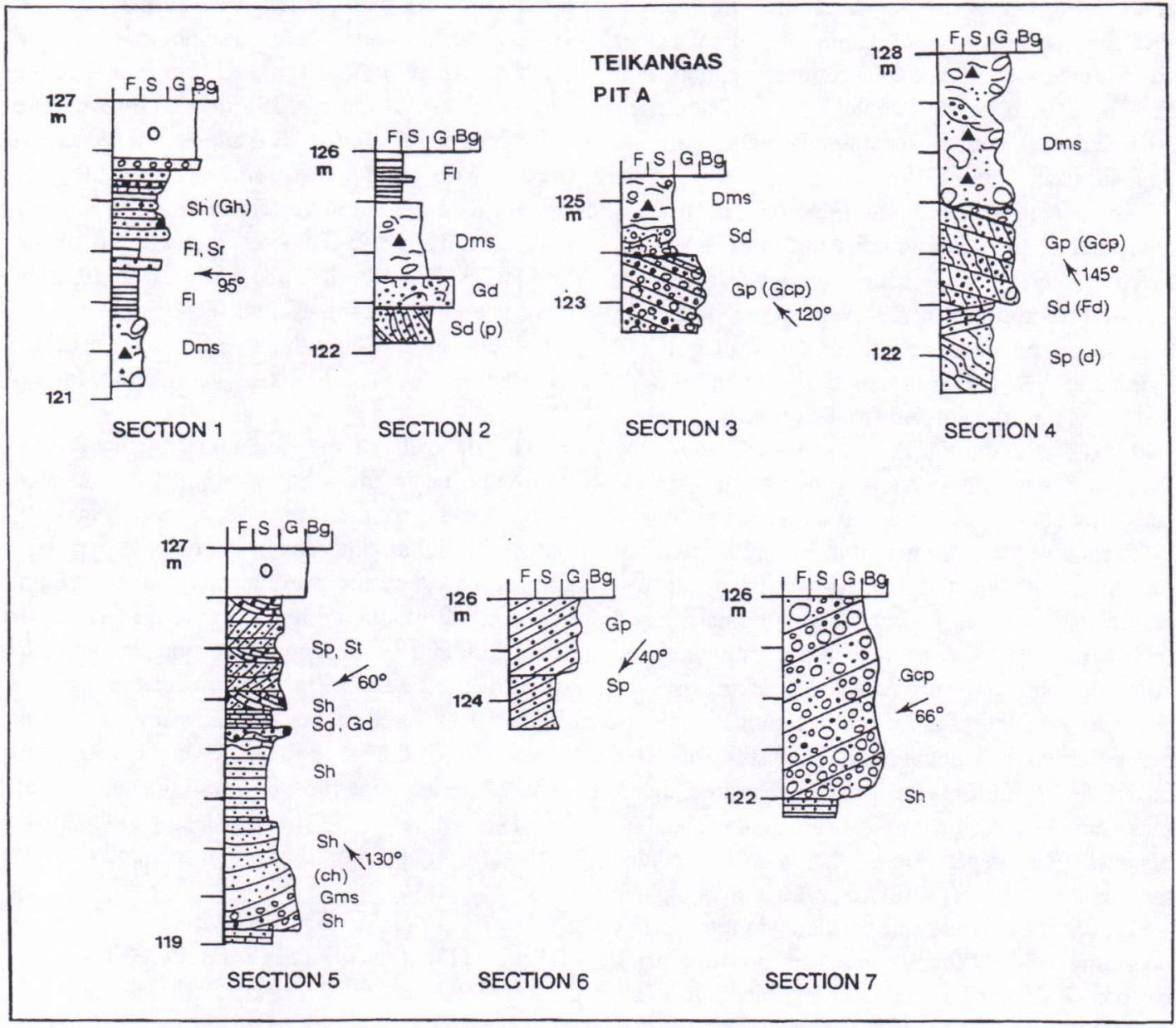

Figure 3. Facies logs from the exposures studied in pit A at Teikangas with palaeoflow directions. Key for facies codes: Grain size; $B g=$ cobble to boulder gravel, $G=$ granule to pebble gravel, $S=$ sand, $F=$ fines (silt and clay). Sedimentary structures: $p=$ planar cross-bedded, $t=$ trough cross-bedded, $h=$ horizontally-bedded, $d=$ deformed, $r=$ ripple-bedded, $l=$ laminated, $m=$ massive. Dms = matrix-supported stratified diamicton, $G c=$ clast supported gravel, $c h=$ channel feature, $i m b=$ clast imbrication, $F l+c=$ clasts in laminated fines. Codes in parentheses indicate minor structural and textural elements in a single sedimentary unit. 


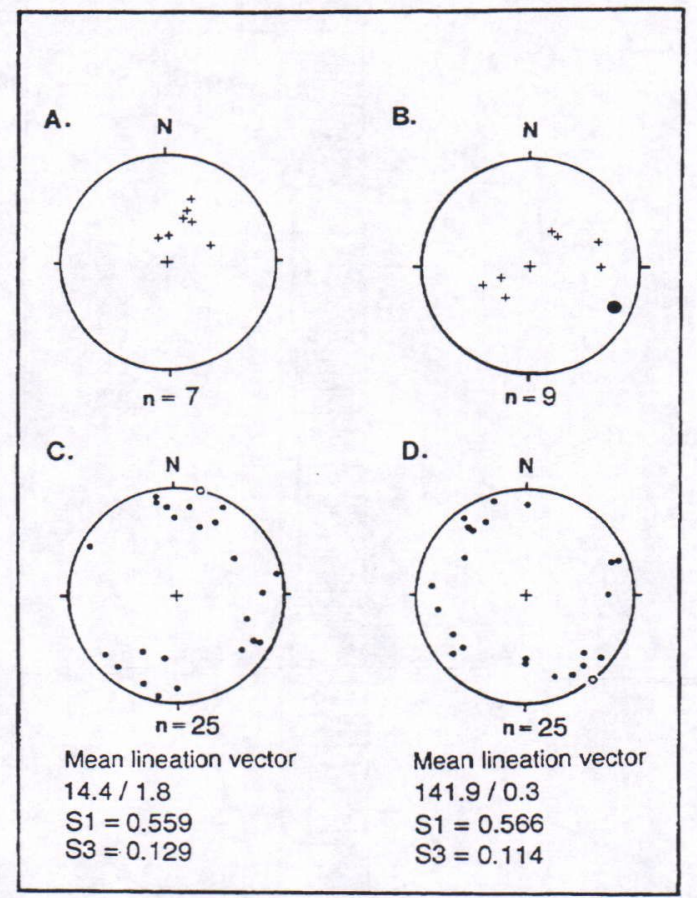

Figure 4. A) Stereographic polar plot (poles to planes) of normal fault planes in cross-bedded sand and gravel of pit A, sections 2 and 4. B) Stereographic polar plot (poles to planes) of fold planes and attitude of a fold axis (black dot) in fold forms at the base of the sand diamicton in pit A, section 2. C) Clast fabric results carried out from stratified sand diamicton in pit A, section 2 (0.25-0.50 $\mathrm{m}$ from the base of the diamicton) and $D)$ in pit A, section $4(0.40-0.60 \mathrm{~m}$ from the base of the diamicton). Mean lineation vectors and eigenvalues $S_{1}$ and $S_{3}$ are also indicated.

diamicton and the underlying, deformed sand and gravel is mainly sharp with some undulation and interdigitation in places. Small-scale folds occur at the base of the sandy diamicton. The orientation of the fold planes and axis in section 2 indicate that the applied deformation stress was from the northeast (Fig. 4B). The clast fabric in the sandy diamicton in sections 2 and 4 shows preferred orientations NNE-SSW and NW-SE, respectively (Fig. 4C, D).

The stratified diamicton is overlain conformably by a laminated mud (facies Fl) in sections 1-
2 (Fig. 3). In section 1, diamicton passes gradually upwards into rhythmites composed of laminated clay and silt with thin sand interlayers. This facies passes upwards into rhythmites composed of laminated silt and clay with thicker sand interbeds (1-4 $\mathrm{cm}$ ) showing current-ripple cross-lamination (facies $\mathrm{Sr}$ ) formed by currents flowing from the east. This rhythmite facies passes upwards into horizontally bedded sand (i.e., plane-parallel stratification) with occasional interbeds of fine gravel (facies Sh (Gh)). The microfossils present in the rhythmite facies are discussed further in the text.

\section{Pit A (sections 5-7)}

Sections 5-7 are located c. $50 \mathrm{~m} \mathrm{NW}$ of sections 1-4 (Fig. 2B). The outcrop is well below the ground surface (the top $8-9 \mathrm{~m}$ has been removed). Considerable lateral facies changes are observed throughout the exposure, but the coarsest deposits occur in section 7. Sections 5 to 7 show predominantly two distinct facies.

The basal unit is gravel and sand with largescale planar cross-bedding, but sands with horizontal bedding, trough cross-bedding and channelfill features are also common (Fig. 3).

In section 5 and further SW from the latter shallow channel-fill features occur in the basal part of the exposures. These palaeochannels are up to $6 \mathrm{~m}$ wide and $2.5 \mathrm{~m}$ deep, infilled with fining-upward sequence comprising matrix-supported stratified gravel (Gms facies) and horizontally bedded sand. The gravel occurs in inversely-graded layers ( $20 \mathrm{~cm}$ thick) overlain by sand $1-5 \mathrm{~cm}$ thick.

Palaeocurrent directions shown by sedimentary structures in the basal unit and the corresponding channel axis trends in section 5 indicate water flow from the southeast. A similar palaeocurrent direction corresponds to the planar cross-bedding exposed between sections 1 and 4 . However, the planar and trough cross-bedded sands above the basal unit in sections 5 and 6 as well as the clastsupported, planar cross-bedded gravel in section 7 , indicate palaeoflow from the northeast (Fig 3). 


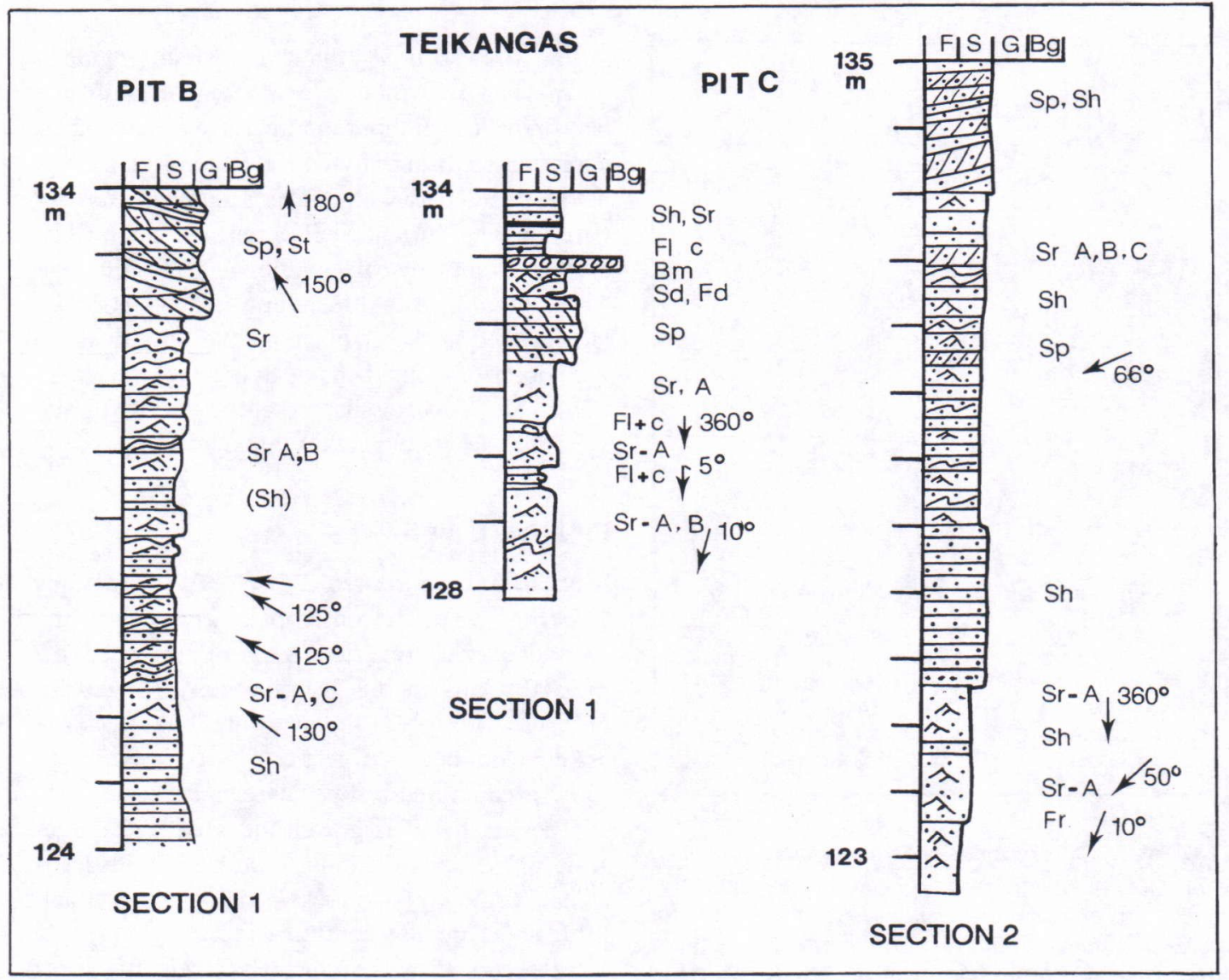

Figure 5. Facies logs from the exposures in pits B and $C$ at Teikangas. For facies codes see caption to Fig. 3.

\section{Pit B (section 1)}

Pit B is located c. $170 \mathrm{~m} \mathrm{NW}$ from pit A (Fig. 2B). The sedimentary succession in pit B shows little lateral variation throughout the $c .100 \mathrm{~m}$ long exposure. The succession in section 1 is approximately $10 \mathrm{~m}$ thick and includes relatively thin units (0.15-1.3 m thick) of sand with horizontal bedding, ripple cross-lamination and climbing cross-lamination of type A, and B (Jopling \& Walker 1968, facies Sh, Sr, Sr-A, B in Fig. 5). The upper $2 \mathrm{~m}$ of the section comprises mainly sand with planar and trough cross-bedding (facies Sp, St in Fig. 5). The contacts between the various types of ripple cross-lamination and also between the latter and the hori- zontal bedding are often gradational, although sharp (but not necessarily erosional) contacts occur as well. In contrast, sharp and erosional contacts characterize the planar and trough crossbedded sand and gravel at the top of the succession and so is their contact with the ripple-laminated sand below. The palaeoflow in section 1 range from south and east (Fig. 5).

\section{Pit C (sections 1-2)}

Pit C is located c. $230 \mathrm{~m}$ north of pit B (Fig. 2B). The exposures in pit $\mathrm{C}$ is more than 12 metres thick and c. $3 \mathrm{~m}$ at the top is missing. The succession shows little lateral variation 
throughout the exposure, except for the uppermost part. The deposits are sand with predominantly ripple cross-lamination and horizontal bedding (facies $\mathrm{Sr}, \mathrm{Sr}-\mathrm{A}, \mathrm{B}, \mathrm{C}, \mathrm{Sh}$ ); there are also some planar cross-bedded sets as well as ripple cross-laminated and rhythmically bedded silt units (Fig. 5). The sediments here are finergrained compared to those in pit B and dropstones are frequent in silt-rich beds. Palaeocurrents in the basal part of the sections 1 and 2 are predominantly from the north, whereas in the upper part of the exposure they are from the east/northeast (Fig. 5).

\section{Pit D (sections 1-2)}

Pit D is located north of pit A (Fig. 2B) and shows two relatively well-exposed sections. The lateral extent of section 1 is over $50 \mathrm{~m}$ and that of section 2 over $40 \mathrm{~m}$. The basal c. $7 \mathrm{~m}$ of section 1 show faintly planar cross-bedded, clastsupported boulder gravel (boulders $0.5-1 \mathrm{~m}$ in diameter) that alternates with fining-upward units of matrix-supported gravel with a mean clast-size of 1-4 cm (Fig. 6). These basal deposits are overlain by matrix-supported, stratified gravel, and horizontally bedded and planar crossbedded sand (facies $\mathrm{Gms}, \mathrm{Sp}$, Sh in Fig. 6). Palaeocurrent in this section is from the northeast.

Section 2 is located $200 \mathrm{~m} \mathrm{NE}$ from section 1 . The basal part of the exposure comprises poorly sorted, matrix-supported gravel with planar crossbedding (Fig. 6) and clasts less than $5 \mathrm{~cm}$ in diameter. This basal unit is overlain by a clast-supported, planar cross-bedded gravel with clasts up to $10 \mathrm{~cm}$ in diameter. The contact between these two units is sharp and erosional. The overlying unit is fining-upward sand with crude horizontal bedding and isolated clasts $1-10 \mathrm{~cm}$ in diameter. The topmost unit is a laminated mud with an interbed of fine-grained, matrix-supported, stratified diamicton containing dropstones. The planar cross-bedding indicates palaeocurrent from the northeast (Fig. 6).

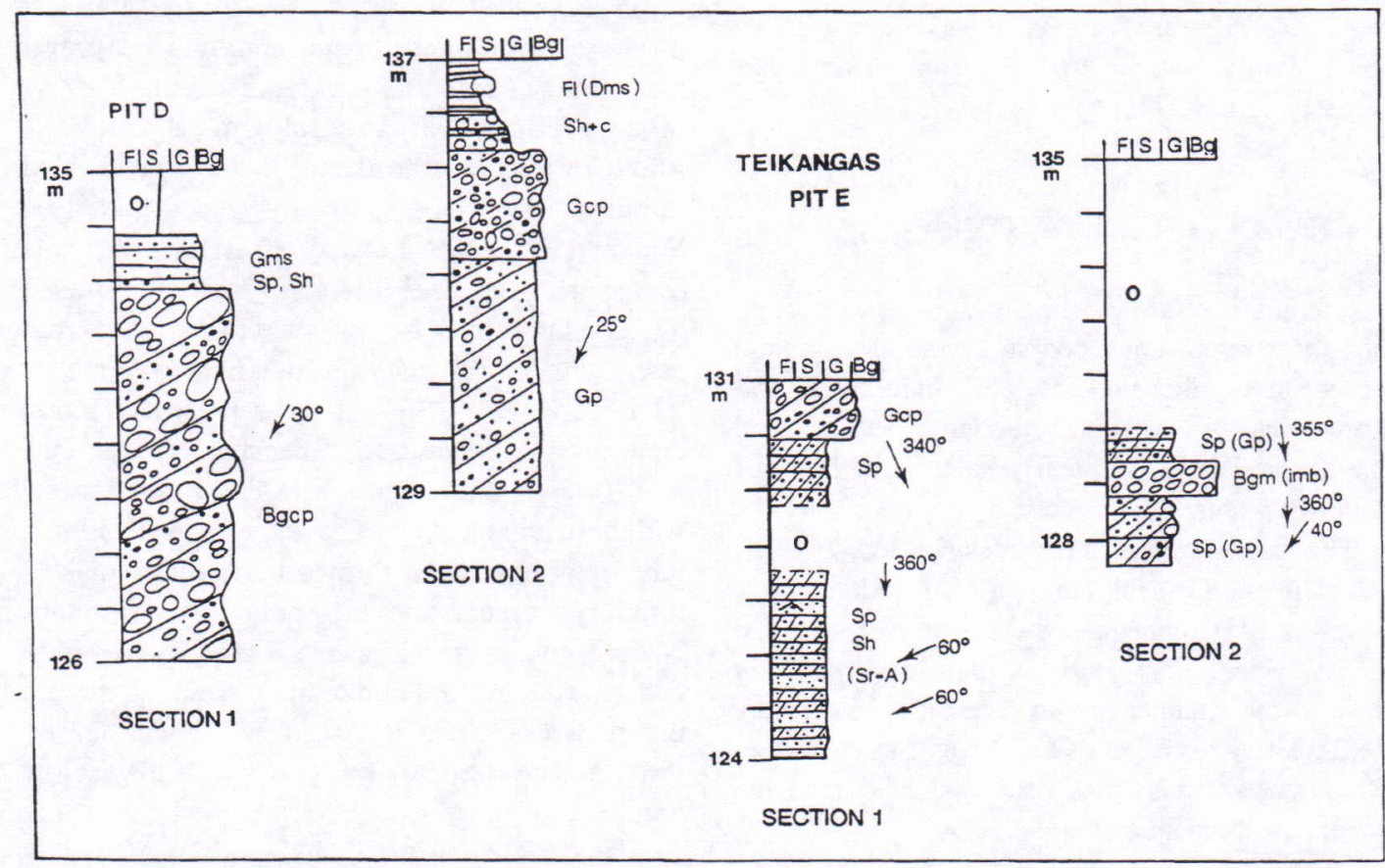

Figure 6. Facies logs from the exposures in pits D and E at Teikangas. For facies codes see caption to Fig. 3. 


\section{Pit E (sections 1-2)}

Two sections have been logged in pit E (Fig. 2B), where most of the exposure is covered by modern talus and vegetation. Section 1 is located in the easternmost part of pit $\mathrm{E}$ and shows, c. 7 $\mathrm{m}$ of the sedimentary succession. The thin units $(10-20 \mathrm{~cm})$ of basal sand here (Fig. 6) are horizontally- and planar cross-bedded also showing type-A climbing ripple cross-lamination. These sand sets are overlain with a sharp contact by clast-supported, planar cross-bedded gravel over $1 \mathrm{~m}$ thick, with clasts up to $2-5 \mathrm{~cm}$ in diameter. Palaeocurrent direction is mainly from the northeast and north.

Section 2 is located $150 \mathrm{~m}$ west from section 1 (Fig. 2B) and shows, a $2.5 \mathrm{~m}$ thick interval of the sedimentary succession, excavated $c .5 \mathrm{~m}$ beneath the ground surface. The deposits are planar crossbedded sand and pebbly gravel (Fig. 6) overlain by a $0.5 \mathrm{~m}$ thick unit of cobble gravel with an erosional lower contact. Clasts are imbricated and $5-15 \mathrm{~cm}$ in size. A sand unit, $0.5 \mathrm{~m}$ thick, with mainly planar cross-bedding overlies the cobble gravel and contains some intercalations of planar cross-bedded pebbly gravel. Palaeocurrent direction is mainly from the north but from the northeast in the basal unit (Fig. 6).

\section{FACIES INTERPRETATION}

The facies assemblage in the Teikangas area is thought to represent a coarse-grained subaquatic fan system. The presence of diamictons and dropstones indicates an ice-contact setting, and fine-grained facies indicate a substantial body of standing water.

The large-scale planar cross-bedded, boulder gravel in pit D (sections 1 and 2) and in pit A (sections 2-7) represents the upper part of a fan foreset facies, most probably deposited relatively close to the channel mouth (see Smith \& Ashley 1985). These gravel beds are thought to have been laid down as debris flows that avalanched down the steep, subaquaeous fan slope.
The alteration of boulder foreset beds and normally-graded, pebbly foreset beds in pit $\mathrm{D}$ (section 1) indicates sediment pulses or surges at the fan front. Imbricated clasts, a-axis parallel to ab-dip direction, in the clast-supported, boulder gravel indicate deposition from high-concentration, nonturbulent (laminar shear) mass flows dominated by clast collisions similar to those described by Rust and Romanelli (1975) and Rust (1988). Normal grading indicates more turbulent gravely mass flows. The coarsest gravel deposits in pit $\mathrm{D}$, section 1 are probably lateral equivalent of those in pit $\mathrm{D}$, section 2 and pit A, sections 5-7, and most likely represents the axial part of the subaquaeous fan system.

In pit $\mathrm{A}$, section 5 and its vicinity, the finingupward deposits grading from matrix-supported, bedded gravel into bedded sand occur in a number of channels, probably fan-slope chutes similar to those described by Nemec (1990). These are likely deposits of gravity flows that originated at the stream mouth and evolved subaqueously into highdensity turbidity currents (cf. Lowe 1982, Nemec, 1990). At least one of the channel-fills shows an inversely-graded gravel unit $(15-20 \mathrm{~cm}$ thick) at the base, overlain by a normally-graded gravel unit. This bipartite unit may represent the freezing of a traction carpet (inversely-graded part) followed directly by the deposition of gravel from turbulent suspension (normally-graded part) (see Walker 1975, 1977, Lowe 1982). However, most of the main channel-fills show normally-graded gravel units at the base attributed to the latter process. These gravel units are overlain by horizontally-bedded sand that may represent traction deposition of waning high-density turbidite currents (Lowe 1982). Laterally extensive sand sheets with horizontal bedding above the channel-fill features may have been formed by non-channelized turbidity currents, possibly spilling over from adjacent active chutes. Planar and trough cross-bedded sands above the horizontally-bedded ones are interpreted as dunes deposited from lower-density turbidity currents, in the upper part of lower flow regime.

The deposits in pit B are sands with mainly climbing-ripple cross-lamination and horizontal 
bedding, probably lateral or more distal relative to the deposits in pit A. Horizontally-bedded sands and ripple-cross lamination are interpreted to have been deposited from semi-continuous, low-density turbidity currents (sustained), whose flow strength varied from upper to lower flow regime. The abundance of the climbing-ripple cross-lamination indicates relatively high rate of suspension fallout during the traction transport of sand. The thicker planar cross-bed sets, $0.3-0.5 \mathrm{~m}$, at the top of section B are attributed to 2-D dunes (see Ashley 1990).

The deposits in pit $\mathrm{C}$ are similar to those in pit $\mathrm{B}$, although show more common planar cross-bed sets and muddy interbeds. The latter contain scattered clasts, which are interpreted as dropstones shed from icebergs or some other type of floating ice; alternatively, these may be clasts that have sporadically rolled down the fan slope.

The exposure in pit $\mathrm{E}$ is poor, but the relatively coarse deposits there show large-scale planar cross-bedding and are interpreted as the proximal / axial part of the fan foreset.

The matrix-supported, silt diamicton that rests conformably on the fan foreset sand in pit A, section 1 and pit D, section 2 is attributed to the subaqueous mass-flows of glacial debris, combined with suspension fallout similar to those described by Eyles \& Miall (1984), McCabe \& Eyles (1988) and Powell (1990). The lamination has been contorted by the frequent emplacement of dropstones, up to $50 \mathrm{~cm}$ in diameter.

The matrix-supported sandy diamicton overlying the foresets sands in pit A, sections $2-4$ is channelized and of a different origin. This diamicton is thought to be a cohesive debris-flow deposit (cf. Hampton 1979, McCabe et al. 1984, Benn 1989, McCabe \& Eyles 1988). The sandy diamicton in pit A (between sections 2-4) rests on deformed substratum zone, $0.5-2 \mathrm{~m}$ thick. This suggests that deformation occurred during the debrisflow emplacement, accompanied by scouring. Fold structures in the deformed foreset sand and gravel indicate stress that was applied from the northeast (pit A, section 2). The attitudes of normal faults in the foreset suggests a similar stress direction. The fabric of the clasts in the basal part of the sand diamicton is non-random (at $95 \%$ confidence level), with a mean vector of $14.4^{\circ}$ and a mean dip of $1.8^{\circ}$. The fabric corresponds relatively well with the stress-field indicated by the structural data. The diamicton fabric in pit A, section 4 is as well nonrandom (at $95 \%$ confidence level), but with a mean vector of $141.9^{\circ}$ and a mean dip of $0.3^{\circ}$. The eigenvalue ratios, $S_{1} / S_{3}$, in both cases are more typical of sediment gravity flow or deformed lodgement till, rather than a pure lodgement and melt-out till (see Dowdeswell \& Sharp 1986). The lithostratigraphic context and the limited areal occurrence of the sand diamicton also support debris-flow origin. Since the intraclasts of myddy rhythmites in the sand diamicton are analogous to the laminated mud overlying the silt diamicton in pit $\mathrm{A}$, section 1 , it suggests that emplacement of sand diamicton post-dates deposition of silt diamicton and at least part of the waterlain rhythmites.

Laminated muddy rhythmites overlie sand diamicton in pit $\mathrm{A}$, section 2 . The rhythmite structure involves clay- or silt-dominated laminae overlain by silt- or sand-dominated laminae. In the lower part of the section, the fine-grained parts of the couplets are thicker and normally graded, and the contacts between the couplets are gradational. In the upper part, the rhythmites are better defined and their fine-grained parts have sharper contacts with the underlying and overlying sandy parts. The fine material (clay and silt) was probably deposited from suspension during quiet periods, when density overflow or interflow dominated, whereas the coarser material represents underflow events (see Smith \& Ashley 1985).

A tentative palaeogeographic interpretation of the fan formation based on the palaeocurrent patterns (Figs 3, 5 and 6) and the facies interpretation is summarized in Fig. 7. At the early stage, there was apparently subaquatic fan system that prograded towards the northwest in the southern part of the Teikangas area. The host basin was probably a narrow body of standing water (over $70 \mathrm{~m}$ deep; see discussion) that formed between the retreating ice-front and the Hämeenkangas ridge (Fig. 7). At the later stage, when the ice-front had retreated further to the north and the basin increased in size, a new subaquatic fan system developed that first 


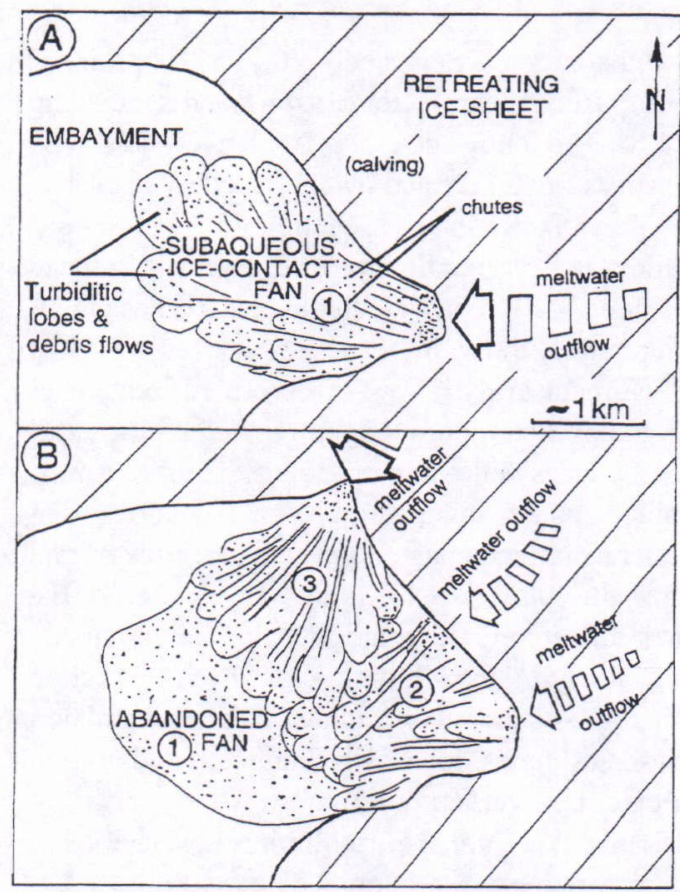

Figure 7. The palaeogeographic interpretation of the Teikangas area during its deposition. A) A subaquatic fan system 1 started to accumulate from the SE into a narrow basin in front of an ice-lobe. B) The basin increased in size and the meltwater + sediment input shifted gradually towards the NE and $N$ producing onlapping subaquatic fan systems 2 and 3.

prograded to the southwest and then shifted gradually towards the south (Fig. 7). As a result of these events the major portion of the fan was formed. Thereafter, waterlain diamicton (silt diamicton) and rhythmites started to accumulate in a relatively quiet waterbody. However, minor oscillations of the ice front (the ice grounding line) could have created the situation that generated cohesive debris flows that produced sand diamicton. After these events a relatively calm conditions were re-established in the basin and deposition of laminated fines continued. Later on, water level fell gradually as a result of relative water level changes in the Baltic Basin and the topmost sediments in pit A (section 1; Sh, Gh facies), pit B (Sp, St facies) and pit D (section $1, \mathrm{Sp}, \mathrm{Sh}, \mathrm{Gms}$ facies) most likely represent littoral deposits.

\section{DIATOM STRATIGRAPHY}

Diatoms in the silt diamicton unit and the rhythmites in pit A, section 1 represent 22 taxa. This relatively low number may be attributed to a poor preservation of the frustules, but it is possible that the original diatom assemblage was quite impoverished due to factors like the low temperature and excessive salinity of the waterbody. In other words, the scarcity of diatoms may imply that the physico-chemical conditions were rather unfavourable to the diatom production, as suggested also by the occurrence of resting spores (e.g., Aulacoseira islandica ssp. helvetica).

The diatom data from pit A, section 1 (Fig. 8) show that the diatom taxa in the basal part of the diamicton unit are characterized by poly- and mesohalobous forms including Grammatophora oceanica, Hyalodiscus scoticus, Rhabdonema arcuatum, Navicula humerosa, Rhopalodia gibberula and Diploneis didyma (Fig. 8A). Among the freshwater taxa, Aulacoseira islandica ssp. helvetica and Tabellaria fenestrata are the most common forms (Fig. 8A). The facultative planktonic sessile Hyalodiscus scoticus is clearly the dominant species $(40 \%)$ in the diamicton samples. Its lower salt tolerance is $c .8 \%$ (Simonsen 1962). According to Mölder \& Tynni (1967), the optimal conditions for Hyalodiscus scoticus are in water with a salt concentration of $1.5-3.0 \%$. The main part of the diatom assemblage in the diamicton comprises benthic-epiphytic species that are typical of coastal littoral zones. The diatom taxa alone indicate deposition in saline or brackish water albeit with some local or temporal freshwater influences (Fig. 8). However, the possibility that the major part of diatoms in silt diamicton have been reworked from older deposits (Eemian) cannot be ruled out.

The diatom assemblage in the muddy rhythmite facies differs markedly from that of the stratified silt diamicton (Fig. 8). In the former, freshwater taxa dominate ( $80 \%$ ) and the bulk of the assemblage consists of planktonic forms characteristic of a pelagic zone (Fig. $8 \mathrm{~B}$ ). Aulacoseira islandica ssp. helvetica is the dominant species, with com- 
A

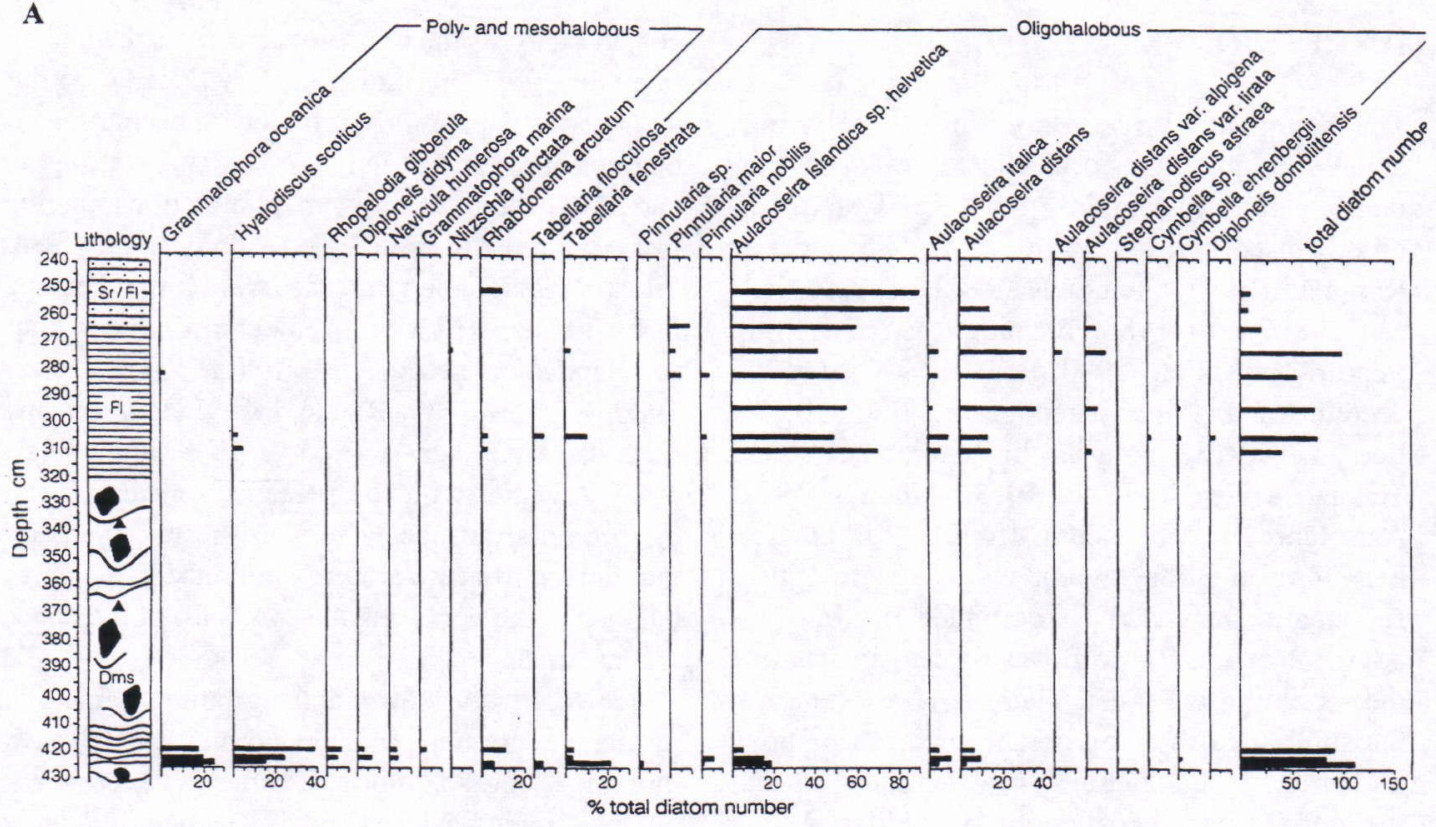

B

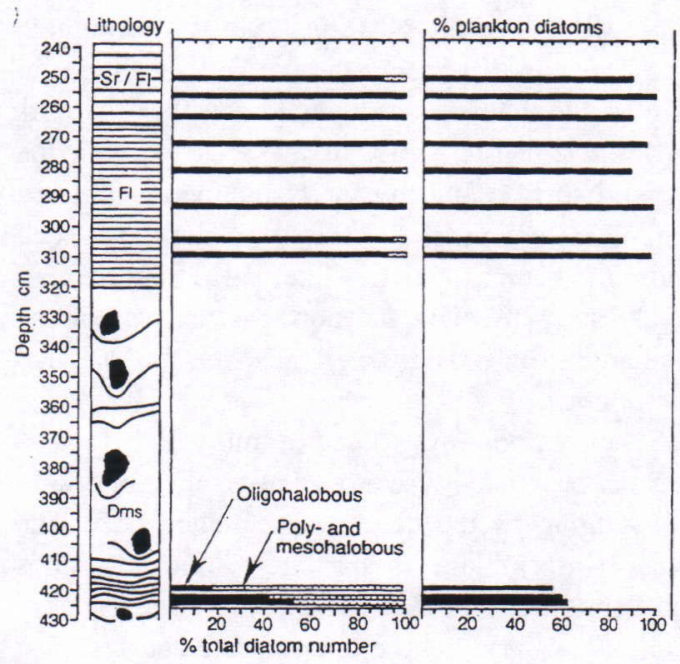

Figure 8. Results of diatom analysis from stratified, silt diamicton and rhythmite facies in pit A, section 1. A) Taxa and percentages of diatom species and B) percentages of oligohalobous and poly / mesohalobous diatoms, and the percentage of planktonic species in total diatom assemblage.

mon Aulacoseira distans, Aulacoseira distans var lirata and Aulacoseira italica in the plankton diatom flora (Fig. 8A). This indicates that the rhyth- mite facies was deposited in a rather quiet freshwater environment. 


\section{DISCUSSION}

The sedimentary succession in the Teikangas area, although exposed in isolated pits only, indicate clearly a complex, local fan system (cf. criteria used by Gustavson et al. 1975, Rust \& Romanelli 1975, Clemmensen \& Houmark-Nielsen 1981, Rust 1988, Burbidge \& Rust 1988, Sharpe 1988, Fyfe 1990, Powell 1990). On the account of the highest recognized Baltic shoreline at $180-182 \mathrm{~m}$ a.s.l. in Vatulanharju near Teikangas (see Virkkala 1963, Alhonen 1971, Aartolahti 1972, Eronen \& Haila 1990), the Teikangas formation would thus represent a subaquatic fan that has prograded into an embayment of the Baltic Basin formed in front of the retreating ice-sheet. There is no exposure in the study area showing deltaic succession above $137 \mathrm{~m}$ a.s.l., but there is little to indicate that the delta topset beds might be hidden in the remaining, unexposed $10 \mathrm{~m}$ of the formation. There is no superficial geomorphologic indication of possible meltwater fluvial channels or kettleholes at the top of the formation, which may mean the presence of delta topset facies deposited close or above the water level (cf. Donner 1951, Price 1971, 1973, Fyfe 1990). If the contemporaneous water level was, indeed, $c$. $182 \mathrm{~m}$ a.s.1., it would have been $c .30 \mathrm{~m}$ above the fan top. This would imply that the Teikangas was an underwater ice-contact fan prograding into a embayment at least $70 \mathrm{~m}$ deep.

The fan sedimentation is inferred to have occurred at the margin of a melting, retreating glacier. There is no evidence of any major esker that might indicate a subglacial feeding conduit (cf. Shreve 1972). Therefore, it is suggested that a linked cavity system (Walder 1986, Sharp et al. 1989) and/or subglacial water sheetflow (Weertman 1972, Alley et al. 1987), rather than a well-defined major channel, could be responsible for the supply of meltwater and sediment to the ice-grounding line in the present case. Smaller subglacial conduits are more unstable than large ones, and thus might have switched their position several times during the development of the Teikangas fan. The palaeocurrent direction and depocentre apparently shifted considerably, as the transport directions deviate by more than $90^{\circ}$. This indicate a curvilinear, irregular ice-margin with multiple outlets. The pattern of bedrock striae in the vicinity of Teikangas is highly varied indicating ice-movement directions ranging from westerly to southerly (Rainio et al. 1986, Punkari 1989), albeit the striae were formed during different phases of ice movement prior to and after the deposition of the CFIMF (cf. Rainio et al. 1986, Punkari 1989, Rainio 1991). However, the bedrock striae data (Rainio et al. 1986, Punkari 1989) together with the palaeocurrent data from the proximal fan facies support the interpretation that the ice front was located not only in the north but also in the northeast and southeast of the depositional area.

Ice-contact fans form at the grounding line of a glacier and normally include morainic bank ('push moraine') ridges comprised of highly heterogeneous tills, including both diamictons and relatively well-sorted outwash deposits (cf. Powell 1981, 1984, 1990, Powell \& Molnia 1989). Although no such deposits are exposed in the Teikangas area, it is possible that some morainic bank facies occurs in the northeastern part of the area, beneath the ground surface and the sandy diamicton unit observed in sections may have originated from such morainic bank ridges. It is likely also that the relatively steep relief in the northeastern part of the Teikangas palaeosystem represents the original ice-contact.

The standing body of water into which Teikangas fan prograded was most likely saline or brackish judging by the diatom assemblage only. The diatom assemblage in the silt diamicton unit is similar to that in the basal deposits in the nearby Lake Kyrösjärvi, where both marine and brackish species occur, including Grammatophora oceanica, Hyalodiscus scoticus, Diploneis didyma and Nitzschia tryblionella (Alhonen 1967, 1971). The Kyrösjärvi assemblage has been correlated with the early Holocene Yoldia Sea stage (Preboreal pollen zone IV) of the Baltic Basin history. It is thought, therefore, that the embayment in the Teikangas area represented the Yoldia Sea. The diatom assemblage in the rhythmite facies, conformably overlying the silt diamicton is clearly 
indicative of a glaciolacustrine environment. The oligohalobous diatoms are comparable with the flora in the freshwater facies of the Yoldia Sea commonly characterized by Aulacoseira islandica ssp. helvetica accompanied by planktonic species (e.g., Alhonen 1979). Studies of the Yoldia Sea sediments at Kyrösjärvi have shown that the freshwater plankton (Aulacoseira islandica ssp. helvetica) increases upwards in abundance and reaches a maximum $(95 \%)$ at the transition from the Yoldia Sea deposits to the subsequent Ancylus Lake deposits (pollen zone boundary IV/V; Alhonen 1971). This indicates that the latest phase of the Yoldia Sea evolution was a freshwater stage, and this supports the conclusion that the silt diamicton and the overlying freshwater rhythmite facies in the Teikangas area was probably deposited at the late phase of the Yoldia Sea.

It has been argued, that the saline stage of the Yoldia Sea is hardly detectable north of the Salpausselkä area (Eronen 1974, Hyvärinen \& Eronen 1979). For example, Eronen (1974) has reasoned that the recognition of the Yoldia phase solely on the base of diatom assemblages may lead to erroneous interpretations, since the Yoldia diatom flora may comprise largely reworked and redeposited fossils derived from the Eemian interglacial sediments. This suggestion seems to be valid for many of the localities where the diatom assemblages comprise both freshwater and saline-water taxa mixed in variable proportions including the area presented here. However, the sedimentary evidence at Teikangas indicates continuous sedimentation with the silt diamicton (containing brackish or saline diatoms) passing gradually upwards into the glaciolacustrine rhythmite facies (containing freshwater diatoms), may also be interpreted as representing the environmental change in water salinity.

\section{CONCLUSIONS}

It is concluded that the Teikangas formation in southwestern Finland represents an underwater ice-contact fan that prograded into the Yoldia Sea during the general retreat of the Scandinavian ice-sheet. The Näsijärvi-Jyväskylä Ice Lobe of the ice-sheet, which had retreated towards the northeast, supplied the meltwater and abundant coarse sediment to the grounding line, most probably through a network of interlinked cavities or small, branching subglacial channels. The transport directions shifted gradually from northwestwardly to southwestwardly (SW and S), probably due to the ice-calving processes and subglacial conduit switching.

No evidence was found of any major readvance of the ice in the area since the diamicton unit in the sedimentary sequence does not represent till i.e. was not directly laid down by the ice-sheet but was deposited as a result of a cohesive debris flow.

ACKNOWLEDGEMENTS: The authors wish to thank V. P. Salonen and P. Gibbard for their critical and very thorough review of the manuscript. The authors are also very grateful to W. Nemec for his suggestions and a critical review that considerably improved the quality of this paper. 


\section{REFERENCES}

Aartolahti, T. 1972. On deglaciation in southern and western Finland. Fennia 114, 84 pp.

Alhonen, $P$. 1967. Palaeolimnological investigations of three inland lakes in south-western Finland. Acta Botanica Fennica 76, 59 pp.

Alhonen, $P .1971$. On the early Flandrian stratigraphy and vegetational history of the North Satakunta area, western Finland. Bulletin of the Geological Society of Finland 43, 39-46.

Alhonen, P. 1979. The Quaternary History of the Baltic. Finland. In Gudelis, V. \& Königson, L. K. (eds): The Quaternary History of Baltic. Acta Universitatis Upsaliensis, Symposia Universitatis Upsaliensis, Annum Quigentesimum Celebrantis 1, 101-113.

Alley, R.B., Blakenship, D.D., Bentley, C.R. \& Rooney, S.T. 1987. Till beneath the Ice Stream B. 3. Till deformation: evidence and implications.Journal of Geophysical Research 92 B9, 8921-8929.

Ashley, G.M. 1990. Classification of large-scale subaqueous bedforms: A new look at an old problem. Journal of Sedimentary Petrology 60, 160-172.

Benn, D.I. 1989. Controls on sedimentation in a Late Devensian ice-dammed lake, Achnasheen, Scotland. Boreas 18, 31-42.

Burbidge, G.H. \& Rust, B.R. 1988. A Champlain Sea Subwash Fan at St. Lazare, Québec. In Gadd, N.R. (ed.): The Late Quaternary Development of the Champlain Sea Basin. Geological Association of Canada, Special Paper 35, 47-61.

Clemmensen, L.B. \& Houmark-Nielsen, M. 1981. Sedimentary features of a Weichselian glaciolacustrine delta. Boreas 10, 229-245.

Donner, J.J. 1951. Pollen-analytical studies of Late Glacial deposits in Finland. Bulletin de la Commission Géologique de Finlande 154, 1-92.

Dowdeswell, J.A. \& Sharp, M.J. 1986. Characterization of pebble fabrics in modern terrestrial glacigenic sediments. Sedimentology 33, 699-710.

Dreimanis, A. 1976. Tills: their origin and properties. In Legget, R. F. (ed.): Glacial till. Royal Society of Canada, Special Publication 12, 11-49.

Eronen, M. 1974. The history of the Litorina Sea and associated Holocene events. Societas Scientiarum Fennica, Commentationes Physico-Matematicae 44, 79-195.

Eronen, M. \& Haila, H. 1990. The main ancient shorelines. In Alasalmi, P. (ed.): Atlas of Finland, folio 124. National Board of Survey \& Geographical Society of Finland, Helsinki (Map).
Eyles, N., Eyles, C.H. \& Miall, A.D. 1983. Lithofacies types and vertical profile models; an alternative approach to the description and environmental interpretation of glacial diamict and diamictite sequences. Sedimentology 30, 393-410.

Eyles, N. \& Miall, A.D. 1984. Glacial Facies. In Walker, R. G. (ed.): Facies Models. Geoscience Canada, Reprint Series 1, 15-38.

Fyfe, G.J. 1990. The effect of water depth on ice-proximal glaciolacustrine sedimentation: Salpausselkä I, southern Finland. Boreas 19, 147-164.

Gustavson, T.C., Ashley, G.M. \& Boothroyd, J.C. 1975. Depositional sequences in glaciolacustrine deltas. In Jopling, A. V. \& McDonald, B. C. (eds): Glaciofluvial and Glaciolacustrine Sedimentation. Society of Economic Palaeontologists and Mineralogists, Special Publication 23, 264-280.

Hampton, M.A. 1979. Buoyancy in debris flows. Journal of Sedimentary Petrology 49, 753-758.

Hyvärinen, H. \& Eronen, M. 1979. The Quaternary history of the Baltic. The northern part. In: Gudelis, V. \& Königsson, L-K. (eds): The Quaternary History of the Baltic, 7-27. Almqvist \& Wiksell, Uppsala.

Jopling, A.V. \& Walker, G.G. 1968. Morphology and origin of ripple-drift cross lamination, with examples of the Pleistocene of Massachusetts. Journal of Sedimentary Petrology 38, 971-984.

Kujansuu, R. \& Niemelä, J. (eds) 1984. Suomen maaperä - Quaternary Deposits of Finland. Geologian Tutkimuskeskus, Espoo. (Map).

Lowe, D.R. 1982. Sediment gravity flows II, Depositional models with some special reference to the deposits of high-density turbidity currents. Journal of Sedimentary Petrology 52, 279-297.

Lunkka, J.P. 1994. Sedimentation and lithostratigraphy of the North Sea Drift and Lowestoft Till Formations in the coastal cliffs of northeast Norfolk, England. Journal of Quaternary Science 9, 209-233.

Lunkka, J.P. and Gibbard, P. (in review). Ice marginal sedimentation and its implication for ice-lobe deglaciation patterns in the Baltic region: Pohjankangas, western Finland. Journal of Quaternary Science.

McCabe, A.M., Dardis, G.F. \& Hanvey, P.M. 1984. Sedimentology of a late Pleistocene submarine-moraine complex, County Down, Northern Ireland. Journal of Sedimentary Petrology 54, 716-730.

McCabe, A.M. \& Eyles, N. 1988. Sedimentology of an ice-contact glaciomarine delta, Carey Valley, Northern Ireland. Sedimentary Geology 59, 1-14.

Mölder, K. \& Tynni, R. 1967. Über Finnlands rezente un subfossile Diatomeen I. Comptes Rendus de la Société géologique de Finlande 39, 199-217. 
Nemec, W. 1990. Aspects of sediment movement on steep delta slopes. In Colella, A. and Prior, D. B. (eds): Coarse-Grained Deltas, 29-73. Special Publication No 10 of the International Association of Sedimentologists. Blackwell Scientific Publications.

Nenonen, K. 1992. Till stratigraphy in southern and western Finland. Bulletin of the Geological Society of Finland 62, 149-160.

Powell, R.D. 1981. A model for sedimentation by tidewater glaciers. Annals of Glaciology 2, 129-134.

Powell, R.D. 1984. Glacimarine processes and inductive lithofacies modeling of ice shelf and tidewater glacier sediments based on Quaternary examples. Marine Geology 57, 1-52.

Powell, R.D. 1990. Processes at glaciomarine grounding line fans and their growth to the ice contact deltas. In Dowdeswell, J. A. \& Scourse, J. D. (eds): Glaciomarine Environments: Processes and Sediments, 53-73. The Geological Society of London, Special Publication.

Powell, R.D. \& Molnia, B.F. 1989. Glacimarine sedimentary processes, facies and morphology of the south-southeast Alaska shelf and fjords. Marine Geology 57, 359-390.

Price, R.J. 1971. The development and destruction of a sandur, Breidamerkurjökull, Iceland. Journal of Arctic and Alpine Research 3, 225-237.

Price, R.J. 1973. Glacial and Fluvioglacial Landforms. Oliver \& Boyd, Edinburgh. 244 pp.

Punkari, M. 1989. Glacial dynamics and related erosion-deposition processes in the Scandinavian ice sheet in south-western Finland. Final Report, Project 01/663, Research Council for the Natural Sciences, Academy of Finland. $86 \mathrm{pp}$.

Rainio, H., Kejonen, A., Kielosto, S. \& Lahermo, P. 1986. Avancerade inlandsisen på nytt också till mellanfinska randformationen? Geologi 4-5, 95-109.

Rainio, H. 1991. The Younger Dryas ice-marginal formations of southern Finland. In Rainio, $\mathrm{H}$. and Saarnisto, M. (eds): Eastern Fennoscandian Younger Dryas end moraines, 25-42. Excursion guide. IGCP project 253, Termination of Pleistocene. Geological Survey of Finland.

Rust, R.B. 1988. Ice-proximal deposits of the Champlain Sea at South Gloucester, near Ottawa, Canada. In Gadd, N. R. (ed.): The Late Quaternary Development of the Champlain Sea Basin. Geological Association of Canada, Special Paper 35, 37-45.

Rust, B.R. \& Romanelli, R. 1975. Late Quaternary subaqueous outwash deposits near Ottawa, Can- ada. In Jopling, A. V. \& McDonald, B. C. (eds): Glaciofluvial and Glaciolacustrine Sedimentation, 177-192. Society of Economic Geologists and Palaeontologists Special Publication 23.

Saarnisto, M. 1991. Chronology of the Salpausselkä end moraines in Finland, and the fluctuation of Baltic Ice Lake levels. In Rainio, H. and Saarnisto, M. (eds): Eastern Fennoscandian Younger Dryas end moraines, 7 -23. Excursion guide. IGCP project 253, Termination of Pleistocene. Geological Survey of Finland.

Sauramo, M. 1958. Die Geschichte der Ostsee. Annales Academiae Scientarum Fennicae, A III, 51, 522 pp.

Sharp, M.J., Gemmell J.C. \& Tilson J-L. 1989. Structure and stability of the former subglacial drainage system of the Glacier de Transfleuron, Switzerland. Earth Surface Processes and Landforms 14, 119-134.

Sharpe, D.R. 1988. Glaciomarine fan deposition in the Champlain Sea. In Gadd, N. R. (ed.): The Late Quaternary Development of the Champlain Sea Basin. Geological Association of Canada, Special Paper 35, 63-82.

Shreve, R. 1972. Movement of water in glaciers. Journal of Glaciology 11, 205-214.

Simonsen, $R$. 1962. Untersuchungen zur Systematik und Ökologie der Bodendiatomeen der westlichen Ostsee. Internationale Revue der Gesamten Hydrobiologie.Systematische Beihefte 1. 144 pp.

Smith, N.D. \& Ashley, G. 1985. Proglacial lacustrine environment. In Ashley, G., Shaw, J. \& Smith, N. (eds): Glacial Sedimentary Environments, 135215. Society of Economic Paleontologists and Mineralogists, 16.

Strömberg, B. 1990. A connection between the clay varve chronologies in Sweden and Finland. Annales Academiae Scientarum Fennicae A III, 154, 32 pp.

Virkkala, K. 1963. On ice-marginal features in southwestern Finland. Bulletin de la Commission Géologique de Finlande, 210, 76 pp.

Walder, J.S. 1986. Hydraulics of subglacial cavities. Journal of Glaciology 32, 439-445.

Walker, R.D. 1975. Generalized facies models for resedimented conglomerates of turbidite association. Bulletin of the Geological Society of America, 86, 737-748.

Walker, R.D. 1977. Deposition of upper Mesozoic resedimented conglomerates and associated turbidites in southwestern Oregon. Bulletin of the Geological Society of America, 88, 273-285.

Weertman, J. 1972. General theory of water flow at the base of a glacier or ice sheet. Review of Geophysics and Space Physics 10 (1), 287-333. 